\title{
Design, Synthesis, and Biological Evaluation of a Potent, PKC Selective, B-Ring Analog of Bryostatin
}

\author{
Paul A. Wender, ${ }^{*}$ Vishal A. Verma \\ Department of Chemistry and Department of Molecular Pharmacology, \\ Stanford University, Stanford, CA 94305-5080
}

Supporting Information

General Methods. All glassware used was oven-dried $\left(>130^{\circ} \mathrm{C}\right)$ and cooled under $\mathrm{N}_{2}$. Stirring was accomplished via magnetic, Teflon ${ }^{\circledR}$-coated stir bars that were oven-dried and cooled under $\mathrm{N}_{2}$. Reactions were sealed with rubber septa or caps and maintained in an inert environment under $\mathrm{N}_{2}$ (passed through calcium sulfate). Solid reagents were measured on a Mettler AK160 balance. Air and moisture sensitive liquids were transferred via dry syringes. Reaction temperatures refer to the temperature that the reaction glassware was immersed. Room temperature is generally between $23-25^{\circ} \mathrm{C}$. Higher temperatures, unless otherwise indicated, were achieved by the use of a silicon oil bath heated by a nichrome wire under constant voltage. A temperature of $-78^{\circ} \mathrm{C}$ was maintained by the use of a dry ice/acetone bath. The term in vacuo refers to the use of a rotary evaporator with an attached vacuum membrane pump. Tetrahydrofuran, toluene, and dichloromethane were passed through alumina drying columns (Solv-tek Inc.) unless otherwise indicated. Ethyl acetate, pentane, and petroleum ether were purchased from Fisher Chemical. Deuterated solvents were purchased from Cambridge Isotope Laboratories. Deuterated chloroform was stored over anhydrous potassium carbonate. Reagents were used as purchased unless otherwise indicated.

Analytical TLC was performed using $0.25 \mathrm{~mm}$ silica gel $60 \mathrm{~F}_{254}$ coated plates from EMD Chemicals Inc. and monitored at $254 \mathrm{~nm}$. Staining was accomplished using $p$-anisaldehyde and gentle heating. Preparative flash chromatography was performed by running solvent under a pressure of air through silica gel (230-400 mech, $60 \AA)$, purchased from Silicycle Chemical Division. Reverse phase high pressure liquid chromatography (RP-HPLC) was performed on a Varian ProStar 320 and monitored at $220 \mathrm{~nm}$. The column used was an Altech Alltima C18 (10 $\mu \mathrm{m}$ ) column (length: $250 \mathrm{~mm}$, inner diamter: $10.0 \mathrm{~mm}$ ). Solvent was removed via sublimation using a Virtis Freezemobile 25EL lyophilizer.

Optical rotations were measured using a JASCO DIP-360 digital machine. The format for measurements are: $[\alpha]_{D}^{\text {temperature }}=$ specific rotation in degrees $(c=$ concentration in $\mathrm{g} / 100 \mathrm{~mL}$, solvent). Nuclear magnetic resonance spectra were taken on a Varian Inova $600\left({ }^{1} \mathrm{H}\right.$ at 600 $\mathrm{MHz})$, Varian Inova $500\left({ }^{1} \mathrm{H}\right.$ at $\left.500 \mathrm{MHz}\right)$, or Varian Mercury $400\left({ }^{1} \mathrm{H}\right.$ at $\left.400 \mathrm{MHz}\right)$ spectrometer. ${ }^{1} \mathrm{H}$ NMR data is reported as follows: chemical shift $(\delta$ in ppm) relative to residual 
solvent peak, integration, multiplicity $(\mathrm{s}=$ singlet, $\mathrm{d}=$ doublet, $\mathrm{t}=$ triplet, $\mathrm{q}=$ quartet, pent $=$ pentent, $\mathrm{dd}=$ doublet of doublets, $\mathrm{ddd}=$ doublet of doublet of doublets, $\mathrm{dddd}=$ doublet of doublet of doublet of doublets, $\mathrm{dt}=$ doublet of triplets, $\mathrm{ddt}=$ doublet of doublet of triplets, $\mathrm{dtt}=$ doublet of triplets of triplets, $\mathrm{m}=$ multiplet), and coupling constant(s). ${ }^{13} \mathrm{C}$ NMR data is reported as follows: chemical shift ( $\delta$ in $\mathrm{ppm}$ ) relative to residual solvent peak. Infrared spectra were measured on a Perkin-Elmer 1600 Series Fourier transform spectrometer, are reported in wavenumbers $\left(\mathrm{cm}^{-1}\right)$, and externally referenced to polystyrene film $\left(1601 \mathrm{~cm}^{-1}\right)$. Purity is documented via high field ${ }^{1} \mathrm{H}$ NMR spectra showing at most only trace peaks not attributable to the assigned structure. High-resolution mass spectra (HRMS) were measured at the highresolution mass spectrometry facility at the University of California, Riverside.

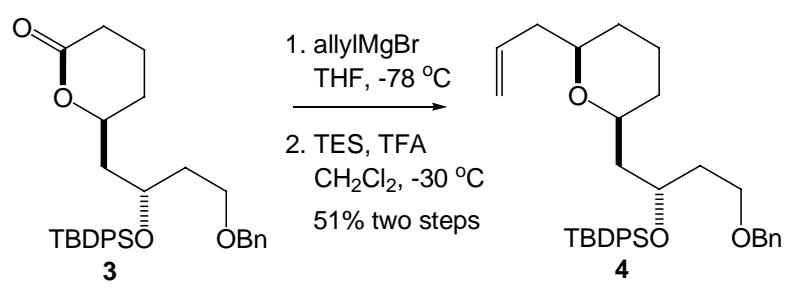

Lactone $3^{\mathrm{i}}$ (259.6 $\left.\mathrm{mg}, 0.501 \mathrm{mmol}\right)$ was dissolved in THF ( $\left.3 \mathrm{~mL}\right)$ and the solution cooled to $-78{ }^{\circ} \mathrm{C}$. AllylMgBr $\left(570 \mu \mathrm{L}, 0.9 \mathrm{M}\right.$ in $\left.\mathrm{Et}_{2} \mathrm{O}, 0.513 \mathrm{mmol}\right)$ was added dropwise via syringe during which time the solution turned pale yellow. After $1.5 \mathrm{~h}$, the reaction was warmed to $\mathrm{rt}$ and quenched with sat. aq. $\mathrm{NH}_{4} \mathrm{Cl}(10 \mathrm{~mL})$. The combined phases were extracted with $\mathrm{Et}_{2} \mathrm{O}(3 \mathrm{x}$ $10 \mathrm{~mL}$ ). The combined organic layers were dried over $\mathrm{MgSO}_{4}$, filtered, and reduced in vacuo. The crude material was dissolved in $\mathrm{CH}_{2} \mathrm{Cl}_{2}(3 \mathrm{~mL})$ and cooled to $-30{ }^{\circ} \mathrm{C}$. Triethylsilane $(800$ $\mu \mathrm{L}, 5.01 \mathrm{mmol})$ and then trifluoroacetic acid $(656 \mu \mathrm{L}, 8.51 \mathrm{mmol})$ were added dropwise. After $1.5 \mathrm{~h}$, the reaction was brought to $\mathrm{rt}$ and quenched with $\mathrm{H}_{2} \mathrm{O}(10 \mathrm{~mL})$ and diluted with $\mathrm{Et}_{2} \mathrm{O}(10$ $\mathrm{mL})$. Extraction with $\mathrm{Et}_{2} \mathrm{O}(3 \times 10 \mathrm{~mL})$ was followed by a sat. aq. $\mathrm{NaHCO}_{3}$ wash $(10 \mathrm{~mL}), \mathrm{H}_{2} \mathrm{O}$ wash $(10 \mathrm{~mL})$, and a brine wash $(10 \mathrm{~mL})$. The organic layer was dried over $\mathrm{MgSO}_{4}$, filtered, and reduced in vacuo. Flash chromatography (1:9 $\mathrm{Et}_{2} \mathrm{O}$ :pet. ether) gave pure 4 (138 mg, 51\%).

Data for 4:

$\mathbf{R}_{f}=0.24$ (5\% EtOAc, 95\% pentane) - one black, UV active spot with p-anisaldehyde stain

IR (film) 3070, 2930, 2856, 1641, 1589, 1472, 1454, 1428, 1389, 1361, 1332, 1263, 1197, 1111 , $1047,1028 \mathrm{~cm}^{-1}$

${ }^{1} \mathrm{H}$ NMR (400 MHz, $\left.\mathrm{CDCl}_{3}\right) \delta 7.70(4 \mathrm{H}, \mathrm{m}), 7.33(11 \mathrm{H}, \mathrm{m}), 5.73(1 \mathrm{H}$, dddd, $J=7.2,7.2,10.0$, $17.2 \mathrm{~Hz}), 5.01(2 \mathrm{H}, \mathrm{m}), 4.35(2 \mathrm{H}, \mathrm{s}), 4.21(1 \mathrm{H}, \mathrm{m}), 3.48(2 \mathrm{H}, \mathrm{t}, J=6.8 \mathrm{~Hz}), 3.33(1 \mathrm{H}, \mathrm{m}), 3.02$ $(1 \mathrm{H}, \mathrm{m}), 2.18(1 \mathrm{H}, \mathrm{m}), 2.05(1 \mathrm{H}, \mathrm{m}), 1.81(2 \mathrm{H}, \mathrm{dd}, J=6.8,12.4 \mathrm{~Hz}), 1.70(1 \mathrm{H}, \mathrm{m}), 1.60(2 \mathrm{H}, \mathrm{m})$, $1.50(1 \mathrm{H}, \mathrm{m}), 1.30(2 \mathrm{H}, \mathrm{m}), 1.05(9 \mathrm{H}, \mathrm{s}), 1.03(2 \mathrm{H}, \mathrm{m})$

${ }^{13} \mathrm{C}$ NMR $\left(100 \mathrm{MHz}, \mathrm{CDCl}_{3}\right) \delta 138.6,135.9$ (x2), 135.9 (x2), 135.3, 134.5, 129.4, 129.4, 128.2 (x2), 127.5, 127.5, 127.4, 127.4, 127.4 (x2), 127.4, 127.3, 116.2, 76.7, 74.3, 72.7, 68.4, 66.9, $44.5,41.0,37.7,31.9,30.8,27.0(x 3), 23.6,19.5$ 
$[\alpha]_{D}^{27}=6.4^{\circ}\left(c=1.79, \mathrm{CDCl}_{3}\right)$
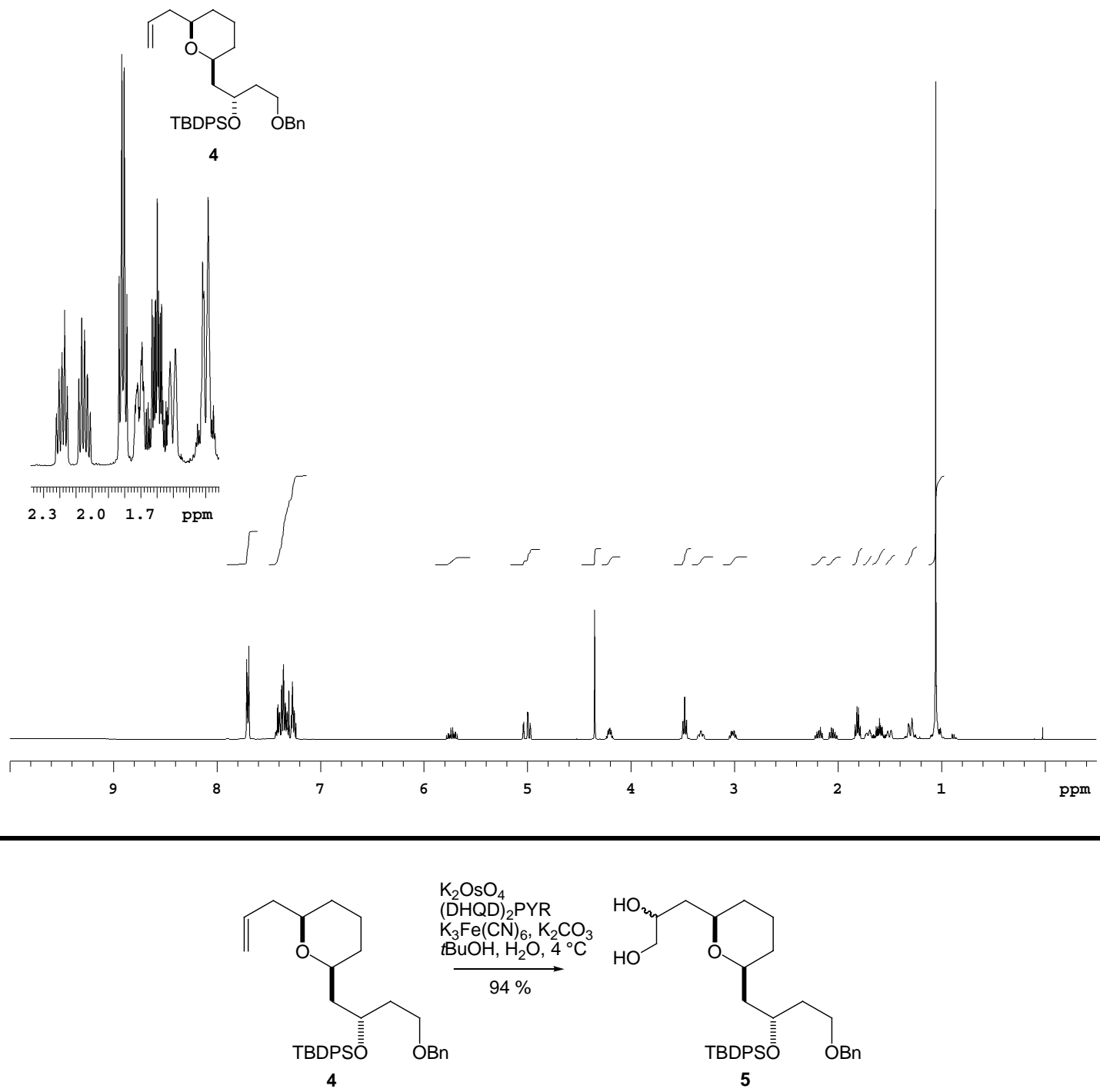

A stock solution was made of $\mathrm{K}_{2} \mathrm{OsO}_{2}(\mathrm{OH})_{4}(1.7 \mathrm{mg}, 0.0046 \mathrm{mmol})$, (DHQD) ${ }_{2} \mathrm{PYR}(9.8$ $\mathrm{mg}, 0.0011 \mathrm{mmol}), \mathrm{K}_{2} \mathrm{CO}_{3}(460.4 \mathrm{mg}, 3.335 \mathrm{mmol})$, and $\mathrm{K}_{3} \mathrm{Fe}(\mathrm{CN})_{6}(1.0920 \mathrm{~g}, 3.318 \mathrm{mmol})$ in $t \mathrm{BuOH}(5.5 \mathrm{~mL})$ and $\mathrm{H}_{2} \mathrm{O}(5.5 \mathrm{~mL})$ and stirred vigorously for $2 \mathrm{~h}$ at $\mathrm{rt}$. An aliquot $(2.21 \mathrm{~mL})$ of this solution was then added via syringe to olefin $4(120.0 \mathrm{mg}, 0.221 \mathrm{mmol})$ at $0{ }^{\circ} \mathrm{C}$ and stirred vigorously for $42 \mathrm{~h}$ at $4{ }^{\circ} \mathrm{C}$. The reaction was then warmed to rt and diluted with $\mathrm{H}_{2} \mathrm{O}(10 \mathrm{~mL})$. The combined phases were extracted with EtOAc $(3 \times 15 \mathrm{~mL})$. The combined organic layers were dried over $\mathrm{MgSO}_{4}$, filtered, and reduced in vacuo. Flash chromatography (1:1 EtOAc:pentane) gave a mixture $(9: 1 \alpha: \beta)$ of diols, which were carried on directly to the next reaction. 

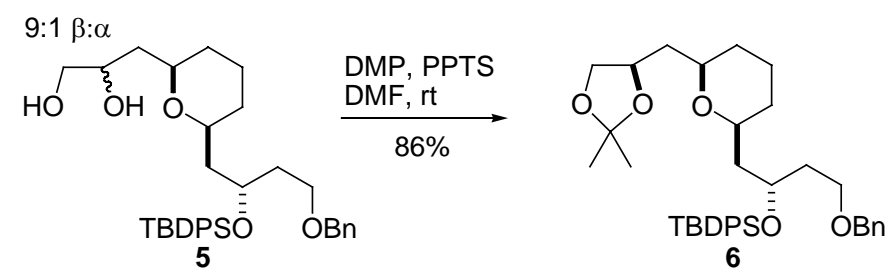

Diol 5 (120.4 mg, $0.209 \mathrm{mmol}$ ) was dissolved in DMF (2 mL). Dimethoxypropane (5.1 $\mathrm{mL}, 41.5 \mathrm{mmol})$ and PPTS $(10.7 \mathrm{mg}, 0.043 \mathrm{mmol})$ were added and the reaction allowed to stir at rt for $2.5 \mathrm{~h}$. The reaction was diluted with aq. sat. $\mathrm{NaHCO}_{3}(15 \mathrm{~mL})$ and $\mathrm{Et}_{2} \mathrm{O}(15 \mathrm{~mL})$. The combined phases were extracted with $\mathrm{Et}_{2} \mathrm{O}(3 \times 10 \mathrm{~mL})$. The combined organic layers were washed with aq. sat. $\mathrm{NaHCO}_{3}(2 \times 10 \mathrm{~mL})$ and brine $(2 \times 10 \mathrm{~mL})$, dried over $\mathrm{MgSO}_{4}$, filtered, and reduced in vacuo. Flash chromatography (1:4 $\mathrm{Et}_{2} \mathrm{O}$ :pet. ether) gave pure 6 (110.2 mg, 86\%).

Data for 6:

$\mathbf{R}_{f}=0.21$ (10\% EtOAc, 90\% pentane) - one black, UV active spot with p-anisaldehyde stain

IR (film) 2930, 2856, 1454, 1428, 1368, 1211, 1111, $1054 \mathrm{~cm}^{-1}$

${ }^{1} \mathrm{H}$ NMR (500 MHz, $\left.\mathrm{CDCl}_{3}\right) \delta 7.67(4 \mathrm{H}, \mathrm{m}), 7.13(11 \mathrm{H}, \mathrm{m}), 4.34(2 \mathrm{H}, \mathrm{s}), 4.12(2 \mathrm{H}, \mathrm{m}), 3.93$ $(1 \mathrm{H}, \mathrm{dd}, J=2.25,8.0 \mathrm{~Hz}), 3.44(3 \mathrm{H}, \mathrm{m}), 3.29(1 \mathrm{H}, \mathrm{m}), 3.16(1 \mathrm{H}, \mathrm{dddd}, J=2.0,6.0,6.0,12.0$ $\mathrm{Hz}), 1.84(4 \mathrm{H}, \mathrm{m}), 1.55(4 \mathrm{H}, \mathrm{m}), 1.40(3 \mathrm{H}, \mathrm{s}), 1.33(3 \mathrm{H}, \mathrm{s}), 1.30(2 \mathrm{H}, \mathrm{m}), 1.11(1 \mathrm{H}, \mathrm{m}), 1.03$ $(9 \mathrm{H}, \mathrm{s}), 0.99(1 \mathrm{H}, \mathrm{m})$

${ }^{13} \mathrm{C}$ NMR (100 MHz, $\left.\mathrm{CDCl}_{3}\right) \delta 138.5,135.9$ (x2), $135.8(\mathrm{x} 2), 134.4,134.4,129.4,129.4,128.2$ (x2), $127.5(\mathrm{x} 2), 127.4(\mathrm{x} 2), 127.4(\mathrm{x} 2), 127.3,108.2,74.3,74.2,72.8,72.7,69.7,68.5,66.8$, $44.5,39.9,37.7,31.7,30.9,29.7,27.0(x 2), 26.9,25.8,23.5,19.4$

HRMS (MALDI ${ }^{+}$) Cacld for $\mathrm{C}_{38} \mathrm{H}_{52} \mathrm{O}_{5} \mathrm{SiNa}$ : 639.3476 Found: 639.3496

$[\alpha]_{D}^{27}=1.2^{\circ}\left(c=2.25, \mathrm{CDCl}_{3}\right)$ 

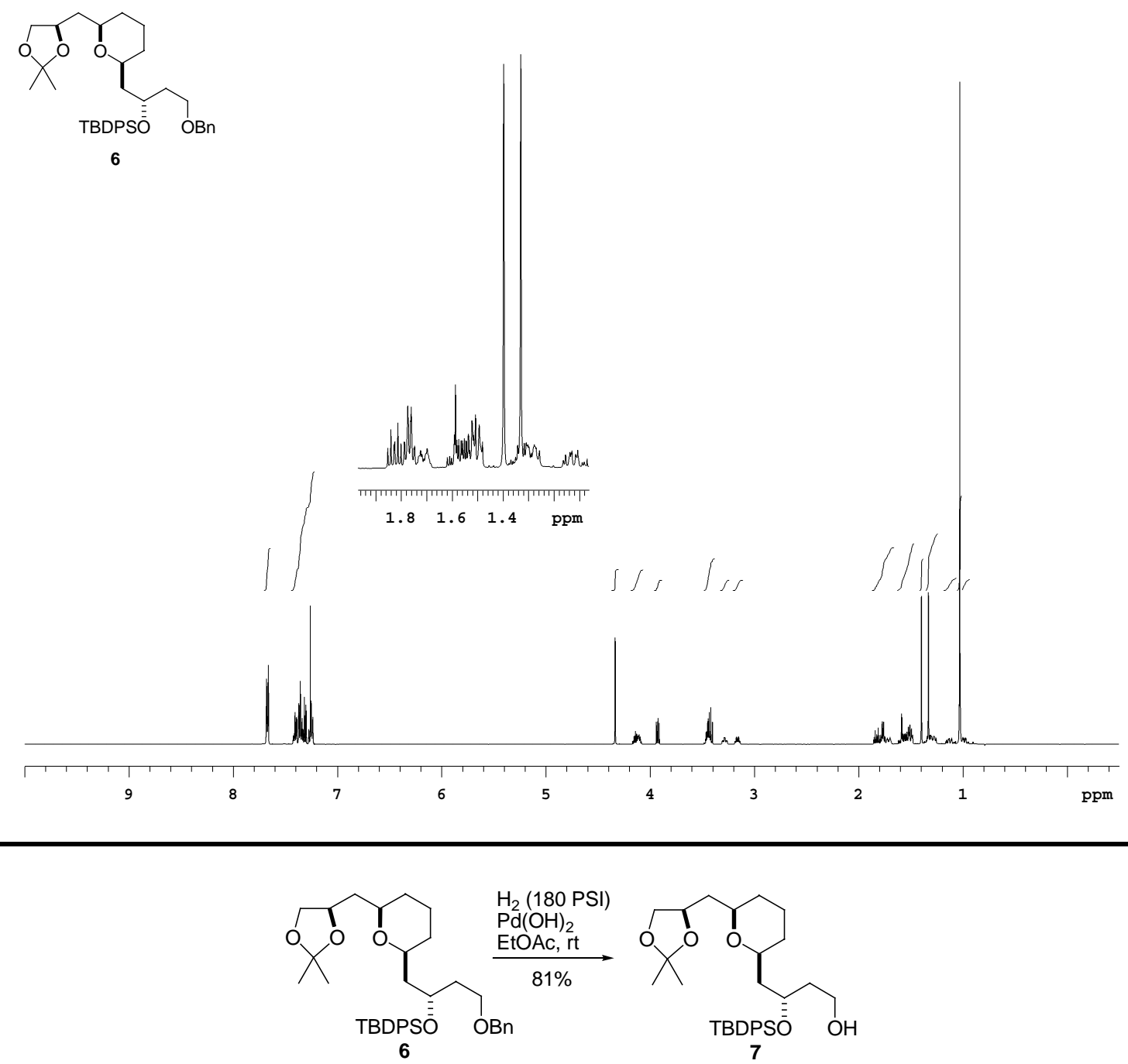

Acetonide 6 (94.9 mg, $0.154 \mathrm{mmol})$ was dissolved in EtOAc $(3 \mathrm{~mL})$ and $\mathrm{Pd}(\mathrm{OH})_{2}(51.4$ $\mathrm{mg}, 0.366 \mathrm{mmol})$ added. The reaction vessel was placed in a bomb and evacuated with $\mathrm{H}_{2}(5 \mathrm{x})$. The $\mathrm{H}_{2}$ pressure was adjusted to $180 \mathrm{PSI}$ and the reaction allowed to stir at $\mathrm{rt}$ for $18 \mathrm{~h}$. The solution was filtered through celite and flash chromatography $\left(3: 2 \mathrm{Et}_{2} \mathrm{O}\right.$ :pet. ether) gave pure alcohol 7 (65.6 mg, 81\%).

Data for 7:

$\mathbf{R}_{f}=0.37$ (30\% EtOAc, 70\% pentane) - one black, UV active spot with p-anisaldehyde stain

IR (film) 3467 (br), 3071, 3050, 2929, 2856, 1473, 1462, 1428, 1378, 1369, 1249, 1214, 1156, $1111,1054 \mathrm{~cm}^{-1}$

${ }^{1} \mathrm{H}$ NMR (500 MHz, $\left.\mathrm{CDCl}_{3}\right) \delta 7.69(4 \mathrm{H}, \mathrm{m}), 7.41(6 \mathrm{H}, \mathrm{m}), 4.10(2 \mathrm{H}, \mathrm{m}), 3.94(1 \mathrm{H}, \mathrm{dd}, J=6.0$, $8.0 \mathrm{~Hz}), 3.75(1 \mathrm{H}, \mathrm{m}), 3.68(1 \mathrm{H}, \mathrm{m}), 3.43(1 \mathrm{H}, \mathrm{t}, J=8.0 \mathrm{~Hz}), 3.13(1 \mathrm{H}, \mathrm{m}), 3.06(1 \mathrm{H}, \mathrm{m}), 2.15$ 
$(1 \mathrm{H}, \mathrm{t}, J=5.5 \mathrm{~Hz}), 1.82(2 \mathrm{H}, \mathrm{m}), 1.71(3 \mathrm{H}, \mathrm{m}), 1.52(3 \mathrm{H}, \mathrm{m}), 1.39(3 \mathrm{H}, \mathrm{s}), 1.33(3 \mathrm{H}, \mathrm{s}), 1.28$ $(1 \mathrm{H}, \mathrm{m}), 1.20(1 \mathrm{H}, \mathrm{m}), 1.11(1 \mathrm{H}, \mathrm{m}), 1.05(9 \mathrm{H}, \mathrm{s}), 0.97(1 \mathrm{H}, \mathrm{m})$

${ }^{13} \mathrm{C}$ NMR $\left(100 \mathrm{MHz}, \mathrm{CDCl}_{3}\right) \delta 135.9(\mathrm{x} 2), 135.8(\mathrm{x} 2), 134.0,133.9,129.7,129.6,127.6(\mathrm{x} 2)$, 127.5 (x2), 108.4, 74.9, 74.5, 72.8, 70.2, 69.6, 59.4, 43.6, 39.8, 39.2, 31.7, 30.8, 27.0 (x3), 26.9, $25.7,23.3,19.3$

HRMS (FAB ${ }^{+}$) Cacld for $\mathrm{C}_{31} \mathrm{H}_{46} \mathrm{O}_{5} \mathrm{SiH}: 527.3192$ Found: 527.3170

$[\alpha]_{D}^{27}=-7.10^{\circ}\left(c=1.11, \mathrm{CDCl}_{3}\right)$
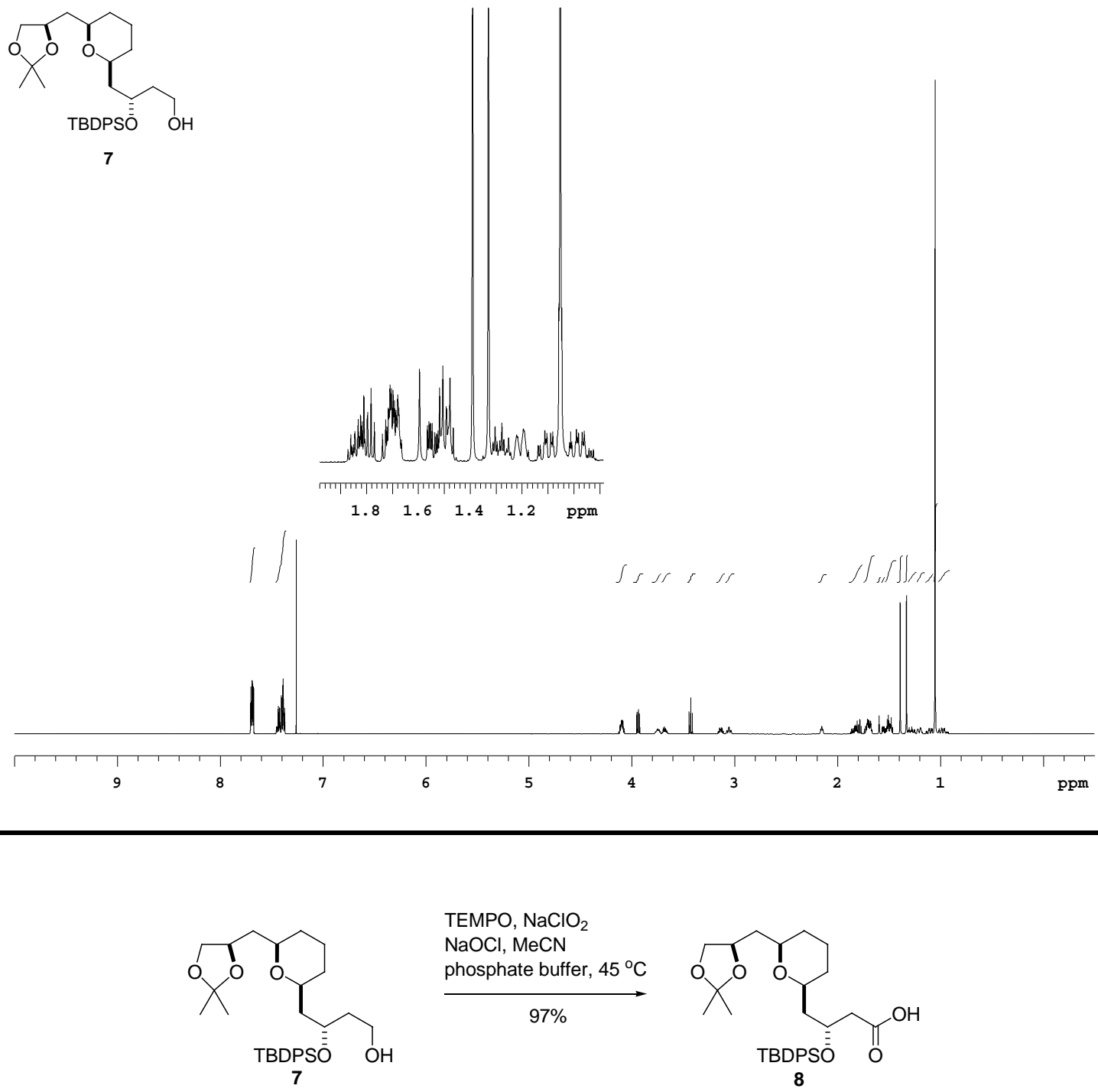

Alcohol 7 (25.0 mg, $0.047 \mathrm{mmol})$ was dissolved in $\mathrm{MeCN}(0.5 \mathrm{~mL})$ and phosphate buffer (pH 7, $0.35 \mathrm{~mL})$. TEMPO $(0.5 \mathrm{mg}, 0.003 \mathrm{mmol})$ was added, followed by sodium chlorite (10.6 $\mathrm{mg}, 0.117 \mathrm{mmol})$. Chlorox ${ }^{\circledR}$ bleach $(120 \mu \mathrm{L})$ was diluted in $\mathrm{H}_{2} \mathrm{O}(1 \mathrm{~mL})$ and an aliquot of this 
solution $(10 \mu \mathrm{L})$ was added to the reaction via syringe. The reaction was allowed to stir for $4 \mathrm{~h}$ at $45^{\circ} \mathrm{C}$. The reaction was cooled to $\mathrm{rt}$ and was adjusted to $\mathrm{pH} 9$ with $\mathrm{NaOH}(0.05 \mathrm{M}, 1.5 \mathrm{~mL})$. The reaction was cooled to $0{ }^{\circ} \mathrm{C}$ and stirred with $\mathrm{Na}_{2} \mathrm{SO}_{3}$ for $30 \mathrm{~min}$. The solution was warmed to $\mathrm{rt}$ and extracted with $\mathrm{Et}_{2} \mathrm{O}(10 \mathrm{~mL})$. The aqueous layer was acidified to ph 4 with $\mathrm{HCl}(1 \mathrm{M})$ and extracted with $\mathrm{Et}_{2} \mathrm{O}(10 \mathrm{~mL})$. The combined organic layers were reduced in vacuo and subjected to flash chromatography (1:3 EtOAc:pentane $+1 \% \mathrm{AcOH})$ to give pure acid 8 (24.6 mg, 97\%).

Data for 8:

$\mathbf{R}_{f}=0.25$ (30\% EtOAC, 70\% pentane) - one black, UV active spot with p-anisaldehyde stain

IR (film) 2930, 2857, 1713, 1428, 1378, 1199, 1156, 1111, $1054 \mathrm{~cm}^{-1}$

${ }^{1} \mathrm{H}$ NMR (500 MHz, $\left.\mathrm{CDCl}_{3}\right) \delta 7.66(4 \mathrm{H}, \mathrm{m}), 7.40$ (6H, m), 4.27 (1H, app quint, $\left.J=5.5 \mathrm{~Hz}\right), 4.09$ $(1 \mathrm{H}, \mathrm{m}), 3.95(1 \mathrm{H}, \mathrm{dd}, J=6.0,8.0 \mathrm{~Hz}), 3.41(1 \mathrm{H}, \mathrm{t}, J=8.0 \mathrm{~Hz}), 3.17(2 \mathrm{H}, \mathrm{m}), 2.56(1 \mathrm{H}, \mathrm{dd}, J=$ $5.5,15.0 \mathrm{~Hz}), 2.52(1 \mathrm{H}, \mathrm{dd}, J=5.5,15.0 \mathrm{~Hz}), 1.79(1 \mathrm{H}, \mathrm{m}), 1.70(2 \mathrm{H}, \mathrm{m}), 1.60(1 \mathrm{H}, \mathrm{ddd}, J=2.8$, 6.5, $14.5 \mathrm{~Hz}), 1.51(2 \mathrm{H}, \mathrm{m}), 1.39(3 \mathrm{H}, \mathrm{s}), 1.32(3 \mathrm{H}, \mathrm{s}), 1.32(1 \mathrm{H}, \mathrm{m}), 1.24(1 \mathrm{H}, \mathrm{m}), 1.13(1 \mathrm{H}, \mathrm{m})$, $1.04(9 \mathrm{H}, \mathrm{s}), 1.03(1 \mathrm{H}, \mathrm{m})$

${ }^{13} \mathrm{C} \mathrm{NMR}\left(100 \mathrm{MHz}, \mathrm{CDCl}_{3}\right) \delta 174.4,135.9(\mathrm{x} 2), 135.9$ (x2), 133.7, 133.4, 129.8, 129.8, 127.7 (x2), 127.6 (x2), 108.5, 74.8, 74.5, 72.9, 69.7, 68.5, 43.8, 39.7, 31.7, 30.7, 26.9, 26.9 (x3), 25.8, $23.3,19.3,19.3$

HRMS (FAB ${ }^{+}$) Cacld for $\mathrm{C}_{31} \mathrm{H}_{44} \mathrm{O}_{6} \mathrm{SiH}: 541.2985$ Found: 541.2981

$[\alpha]_{D}^{27}=-2.42^{\circ}\left(c=1.48, \mathrm{CDCl}_{3}\right)$ 

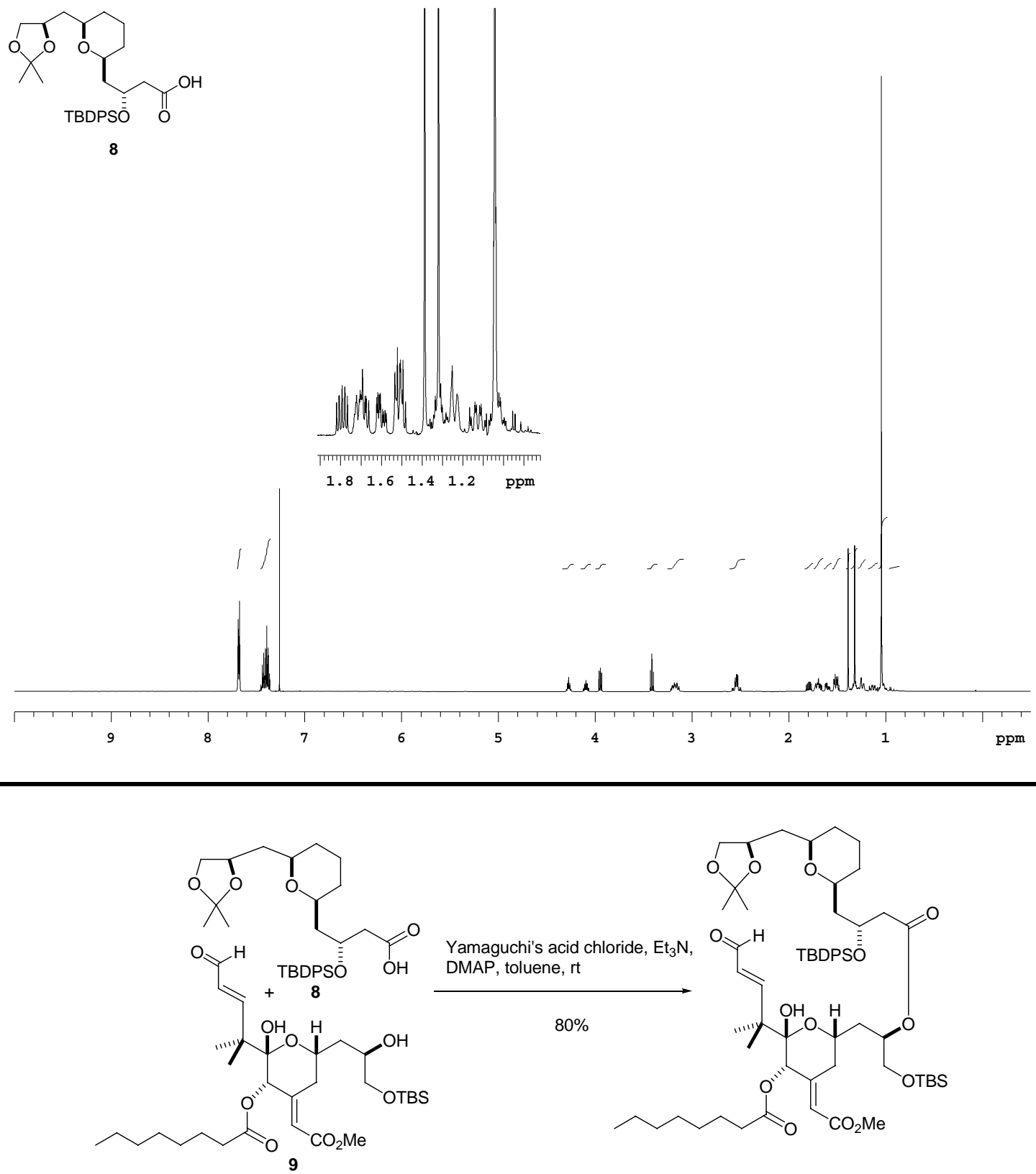

Acid $8(5.4 \mathrm{mg}, 0.0099 \mathrm{mmol})$ was dissolved in toluene $(500 \mu \mathrm{L})$ and $\mathrm{Et}_{3} \mathrm{~N}(5.6 \mu \mathrm{L}$, $0.0402 \mathrm{mmol}$ ) was added, followed by 2,4,6-trichlorobenzoyl chloride $(1.68 \mu \mathrm{L}, 0.108 \mathrm{mmol})$ via syringe. The reaction was allowed to stir at $\mathrm{rt}$ for $5 \mathrm{~h}$. Recognition domain $9(5.7 \mathrm{mg}, 0.0095$ mmol) and DMAP $(5.8 \mathrm{mg}, 0.0475 \mathrm{mmol})$ were dissolved in toluene $(500 \mu \mathrm{L})$ and added to the reaction via syringe during which time the solution turned cloudy. The reaction was allowed to stir for $1 \mathrm{~h}$, after which direct flash chromatography $(1: 9 \rightarrow 1: 4$ EtOAc:pentane) gave the pure aldehyde $(8.5 \mathrm{mg}, 80 \%)$.

Data for aldehyde:

$\mathbf{R}_{f}=0.45$ (20\% EtOAc, $80 \%$ pentane $)$ - one black, UV active spot with p-anisaldehyde stain 
IR (film) 3468 (br), 2930, 2857, 1723, 1690, 1462, 1429, 1379, 1252, 1228, 1155, $1054 \mathrm{~cm}^{-1}$

${ }^{1} \mathrm{H}$ NMR $\left(400 \mathrm{MHz}, \mathrm{CDCl}_{3}\right) \delta 9.55(2 \mathrm{H}, \mathrm{d}, J=7.6 \mathrm{~Hz}), 7.66(4 \mathrm{H}, \mathrm{m}), 7.38(7 \mathrm{H}, \mathrm{m}), 5.99(1 \mathrm{H}, \mathrm{d}$, $J=1.8 \mathrm{~Hz}), 5.95(1 \mathrm{H}, \mathrm{dd}, J=8.0,16.0 \mathrm{~Hz}), 5.17(1 \mathrm{H}, \mathrm{m}), 5.10(1 \mathrm{H}, \mathrm{s}), 4.35(1 \mathrm{H}, \mathrm{m}), 4.10(1 \mathrm{H}$, $\mathrm{m}), 3.92(1 \mathrm{H}, \mathrm{dd}, J=6.0,8.4 \mathrm{~Hz}), 3.76(1 \mathrm{H}, \mathrm{m}), 3.67(3 \mathrm{H}, \mathrm{s}), 3.63(2 \mathrm{H}, \mathrm{m}), 3.40(1 \mathrm{H}, \mathrm{t}, J=8.0$ $\mathrm{Hz}), 3.28(1 \mathrm{H}, \mathrm{m}), 3.17(1 \mathrm{H}, \mathrm{m}), 3.07(1 \mathrm{H}, \mathrm{d}, J=1.4 \mathrm{~Hz}), 2.44(2 \mathrm{H}, \mathrm{m}), 2.05(3 \mathrm{H}, \mathrm{m}), 1.90(1 \mathrm{H}$, $\mathrm{m}), 1.79(1 \mathrm{H}, \mathrm{m}), 1.70(2 \mathrm{H}, \mathrm{m}), 1.51(6 \mathrm{H}, \mathrm{m}), 1.40(3 \mathrm{H}, \mathrm{s}), 1.33(3 \mathrm{H}, \mathrm{s}), 1.25(12 \mathrm{H}, \mathrm{m}), 1.15$ $(3 \mathrm{H}, \mathrm{s}), 1.14(3 \mathrm{H}, \mathrm{s}), 1.00(9 \mathrm{H}, \mathrm{s}), 0.89(9 \mathrm{H}, \mathrm{s}), 0.87(3 \mathrm{H}, \mathrm{t}, J=7.2 \mathrm{~Hz}), 0.51(3 \mathrm{H}, \mathrm{s}), 0.42(3 \mathrm{H}$, s)

${ }^{13} \mathrm{C}$ NMR $\left(100 \mathrm{MHz}, \mathrm{CDCl}_{3}\right) \delta 207.2,194.9,172.2,172.0,166.8,166.6,150.7,136.1(\mathrm{x} 2), 136.1$ (x2), 134.2, 134.2, 129.9, 129.9, 128.6, 127.8 (x2), 127.7, 120.9, 108.6, 99.7, 74.6, 74.1, 73.0, $72.9,71.4,70.0,67.9,66.4,65.1,51.4,45.9,44.7,43.4,40.1,37.8,34.7,31.8,31.2(x 3), 31.0$, $30.0,29.1,29.1,27.2,27.2,26.1(x 3), 24.7,23.7,23.1,22.8,22.3,20.3,19.6,18.5,14.3,-5.1$ (x2)

HRMS (MALDI ${ }^{+}$) cacld for $\mathrm{C}_{62} \mathrm{H}_{96} \mathrm{O}_{14} \mathrm{Si}_{2} \mathrm{Na}: 1143.6231$ Found: 1143.6271

$[\alpha]_{D}^{27}=-27.33^{\circ}\left(c=0.41, \mathrm{CDCl}_{3}\right)$

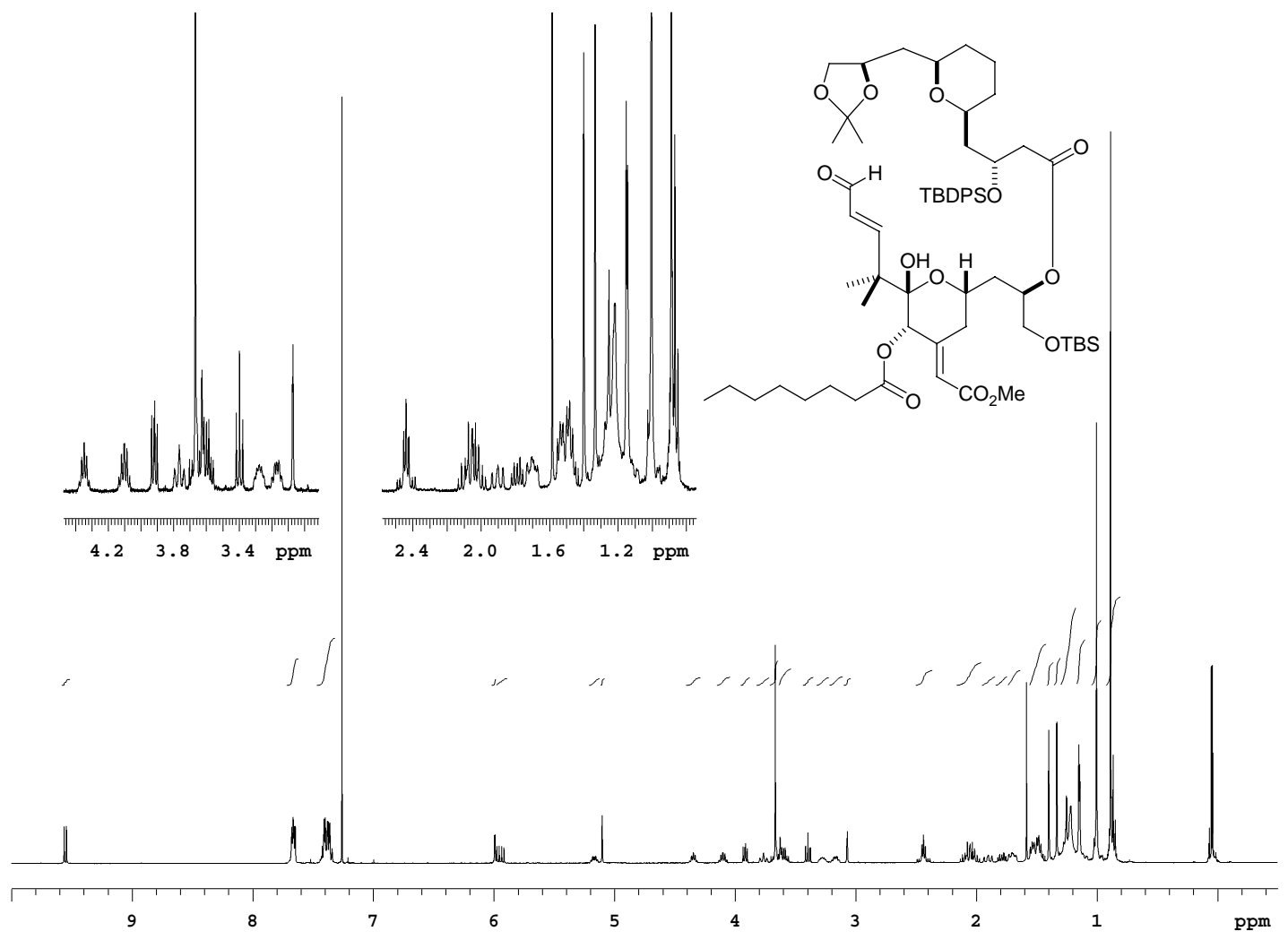




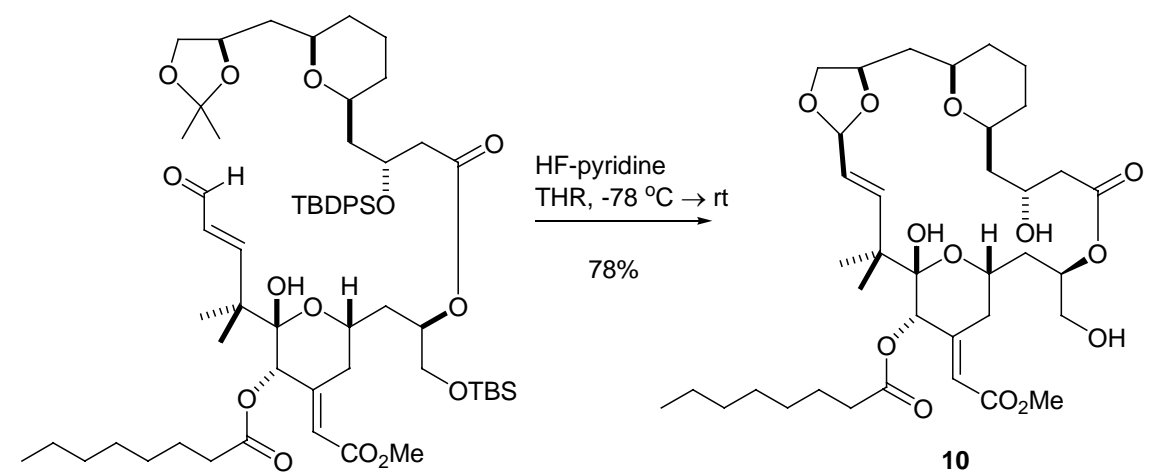

The aldehyde intermediate $(6.3 \mathrm{mg}, 0.0056 \mathrm{mmol})$ was dissolved in THF $(1.8 \mathrm{~mL})$ in a polypropylene vial and cooled to $-78^{\circ} \mathrm{C}$. HF.pyridine was added dropwise via syringe and the reaction allowed to stir at $\mathrm{rt}$ for $37 \mathrm{~h}$. The reaction was quenched with aq. sat. $\mathrm{NaHCO}_{3}(10 \mathrm{~mL})$. The combined phaes were extracted with EtOAc $(4 \times 10 \mathrm{~mL})$, dried over $\mathrm{Na}_{2} \mathrm{SO}_{4}$, filtered, and reduced in vacuo. Flash chromatography gave pure analog 10 as a white solid (3.1 mg, 78\%).

Data for 10:

$\mathbf{R}_{f}=0.40$ (80\% EtOAc, 20\% pentane) - one black, UV active spot with p-anisaldehyde stain

HPLC: Retention Time $=16.00$ min. Method: $65 \% \rightarrow 95 \% \mathrm{MeCN}$ in $\mathrm{H}_{2} \mathrm{O}$ at $6 \mathrm{~mL} / \mathrm{min}$ over 30 $\min$.

IR (film) 3427 (br), 2919, 2850, 1723, 1668, 1411, 1435, 1382, 1298, 1260, 1231, 1159, 1093, $1051,1023 \mathrm{~cm}^{-1}$

${ }^{1} \mathrm{H}$ NMR $\left(500 \mathrm{MHz}, \mathrm{CDCl}_{3}\right) \delta 6.03(1 \mathrm{H}, \mathrm{d}, J=15.5 \mathrm{~Hz}), 5.97(1 \mathrm{H}, \mathrm{d}, J=2.0 \mathrm{~Hz}), 5.39(1 \mathrm{H}, \mathrm{m})$, $5.35(1 \mathrm{H}, \mathrm{dd}, J=7.5,15.5 \mathrm{~Hz}), 5.26(1 \mathrm{H}, \mathrm{d}, J=7.5 \mathrm{~Hz}), 5.21(1 \mathrm{H}, \mathrm{d}, J=12.0 \mathrm{~Hz}), 5.13(1 \mathrm{H}, \mathrm{s})$, $4.88(1 \mathrm{H}, \mathrm{s}), 4.19(2 \mathrm{H}, \mathrm{m}), 4.02(1 \mathrm{H}, \mathrm{m}), 4.01(1 \mathrm{H}, \mathrm{m}), 3.84(1 \mathrm{H}, \mathrm{ddd}, J=3.1,5.0,12.0 \mathrm{~Hz})$, $3.71(1 \mathrm{H}, \mathrm{dd}, J=2.3,14.0 \mathrm{~Hz}), 3.68(3 \mathrm{H}, \mathrm{s}), 3.65(1 \mathrm{H}, \mathrm{m}), 3.49(2 \mathrm{H}, \mathrm{m}), 3.37(1 \mathrm{H}, \mathrm{dd}, J=7.0$, $9.0 \mathrm{~Hz}), 2.58(1 \mathrm{H}, \mathrm{dd}, J=11.5 \mathrm{~Hz}, 13 \mathrm{~Hz}), 2.51(1 \mathrm{H}, \mathrm{dd}, J=2.9,13 \mathrm{~Hz}), 2.29(2 \mathrm{H}, \mathrm{m}), 2.04$ $(1 \mathrm{H}, \mathrm{m}), 2.01(1 \mathrm{H}, \mathrm{m}), 1.99(1 \mathrm{H}, \mathrm{m}), 1.83(1 \mathrm{H}, \mathrm{m}), 1.78(1 \mathrm{H}, \mathrm{m}), 1.75(1 \mathrm{H}, \mathrm{m}), 1.66(1 \mathrm{H}, \mathrm{m})$, $1.60(2 \mathrm{H}, \mathrm{m}), 1.55(1 \mathrm{H}, \mathrm{m}), 1.49(1 \mathrm{H}, \mathrm{m}), 1.26(12 \mathrm{H}, \mathrm{m}), 1.18(3 \mathrm{H}, \mathrm{s}), 1.03(3 \mathrm{H}, \mathrm{s}), 0.87(3 \mathrm{H}, \mathrm{t}, J$ $=6.5 \mathrm{~Hz})$

${ }^{13} \mathrm{C}$ NMR $\left(125 \mathrm{MHz}, \mathrm{CDCl}_{3}\right) \delta 172.7,172.3,167.3,151.7,145.4,125.1,120.0,105.3,100.0$, 77.9, 77.0, 75.0, 73.9, 71.2, 69.8, 68.3, 65.8, 64.7, 51.1, 45.4, 41.9, 40.6, 37.7, 36.1, 34.6, 31.8, $31.5(x 2), 30.9,29.7,29.0,24.6,24.3,23.2,22.5,19.4,14.1$

HRMS (MALDI ${ }^{+}$) cacld for $\mathrm{C}_{37} \mathrm{H}_{58} \mathrm{O}_{13} \mathrm{Na}$ : 733.3770 Found: 733.3789

$[\alpha]_{D}^{27}=-8.9^{\circ}\left(c=0.17, \mathrm{CDCl}_{3}\right)$ 
ROESY stereochemical correlations of $\mathbf{1 0}$ :

\begin{tabular}{|c|c|c|c|c|}
\hline $\begin{array}{c}\text { Proton } \\
\text { correlation }\end{array}$ & $\begin{array}{c}\text { ROESY } \\
\text { volume }\end{array}$ & $\begin{array}{c}\text { Distance calculated from } \\
\text { volume }(\AA)\end{array}$ & $\begin{array}{c}\text { Distance from } \\
\text { modeling }(\AA)\end{array}$ & $\begin{array}{c}\text { Distance from modeling epi- } \\
\text { C15 10 }(\AA)\end{array}$ \\
\hline C15-C11 & 1.9148 & 2.580 & 2.712 & 3.727 \\
\hline C11-C9 & 1.1736 & 2.800 & 2.524 & 2.569 \\
\hline C13 $\alpha-\mathrm{C} 13 \beta$ & 15.2960 & N/A & 1.825 & 1.827 \\
\hline
\end{tabular}

The relationship between ROSEY volumes and distance is calculated using the equation $\mathrm{V} \propto \mathrm{r}^{6}$. The modeling data (MacroModel V7.0 with the Maestro 4.1 interface, Monte-Carlo with MM2 force field in $\mathrm{CHCl}_{3}, 50,000$ steps) gives a distance of $1.825 \AA$ between the geminal $\mathrm{C} 13$ protons, which is within a reasonable limit to the accepted value of $1.75 \AA$ for geminal protons. From this value, all the other relevant distances can be calculated by using the equation $V_{1} / V_{2}=r_{2}{ }^{6} / r_{1}{ }^{6}$ and can be seen to match well with the model of $\mathbf{1 0}$ and not epi-C15 10. The strength of the C15 C11 ROESY correlation confirms the C15 stereochemistry. Moreover, the ROESY correlation of $\mathrm{C} 11$ and $\mathrm{C} 9$ confirms that the Sharpless asymmetric dihydroxylation also resulted in the desired stereochemistry.

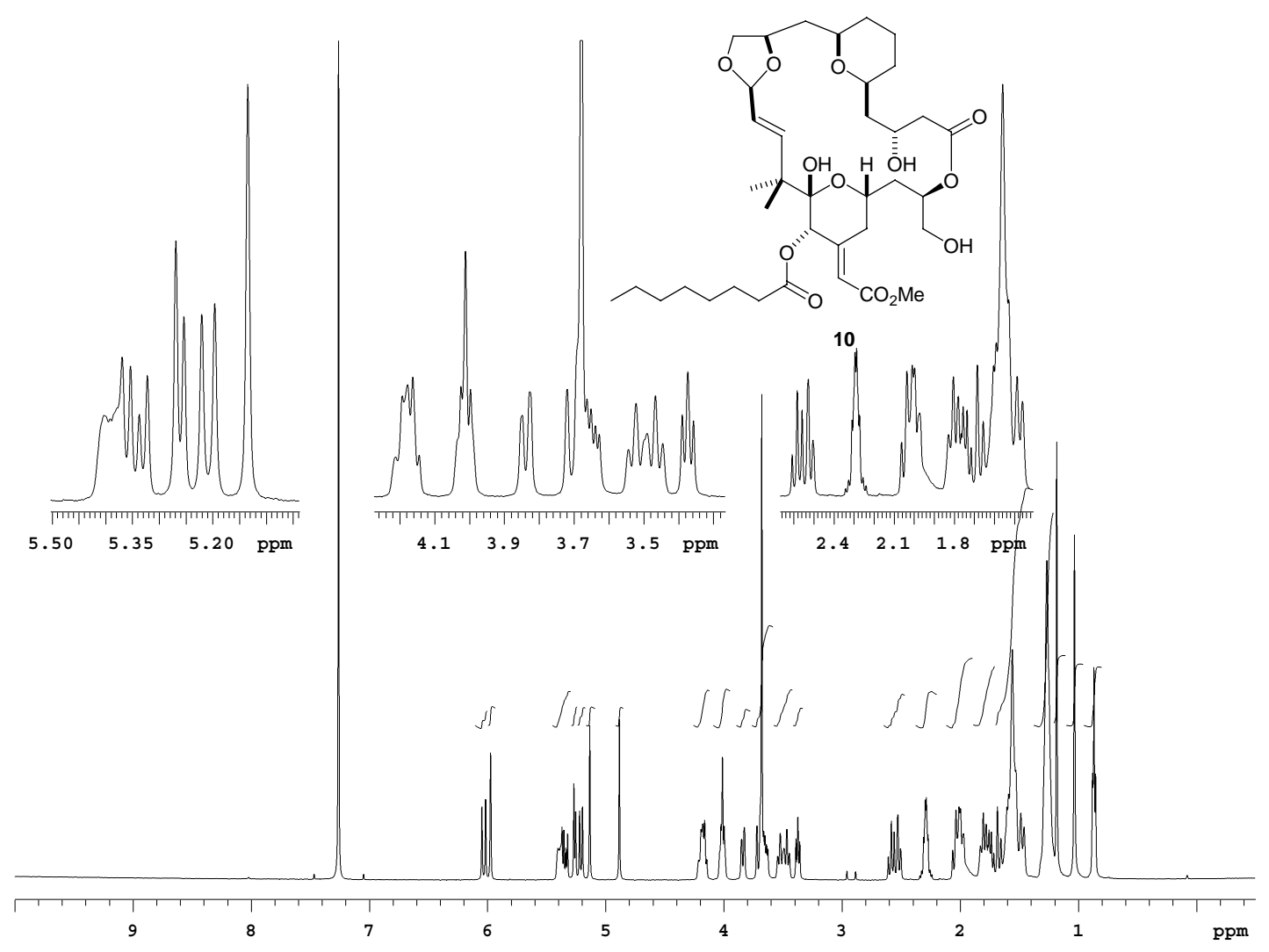

PKC-Isozyme Mixture Binding Assay. ${ }^{\text {ii }}$ In a conical vial, a buffer solution was made consisting of Tris- $\mathrm{HCl}(1 \mathrm{M}, 1 \mathrm{~mL}, \mathrm{pH} 7.4), \mathrm{KCl}(1 \mathrm{M}, 2 \mathrm{~mL}), \mathrm{CaCl}_{2}(0.1 \mathrm{M}, 30 \mu \mathrm{L})$, and bovine serum albumin $\left(40 \mathrm{mg}\right.$ ), which was then diluted to $20 \mathrm{~mL}$ with $\mathrm{H}_{2} \mathrm{O}$ and stored on ice. Phosphatidyl serine vesicles $\left(140 \mu \mathrm{L}, 25 \mathrm{mg} / \mathrm{mL}\right.$ in $\left.\mathrm{CHCl}_{3}\right)$ were prepared by removing the 
chloroform under a stream of nitrogen. The prepared buffer solution was added $(3.5 \mathrm{~mL})$ and the solution was sonicated (Branson Sonifier 250, power $=6,40 \%$ duty cycle) four times for $30 \mathrm{~s}$ with a $30 \mathrm{~s}$ rest in between sonications and stored on ice as a cloudy solution. A mixture of PKC isozymes, prepared by the method of Mochly-Rosen, ${ }^{\text {iii }}$ was prepared by adding a solution of PKC isozymes $(600 \mu \mathrm{L})$ to the prepared buffer solution $(14 \mathrm{~mL})$ and storing on ice. Filters (Whatman GF-B, $21 \mathrm{~mm}$ diameter) were soaked for $1 \mathrm{~h}$ in a solution containing deionized water $(97 \mathrm{~mL})$, and $10 \%$ polyethyleneamine $(3 \mathrm{~mL})$. Final assay vials were prepared in triplicate by adding the phosphatidyl serine solution $(60 \mu \mathrm{L})$, PKC solution $(200 \mu \mathrm{L})$, and diluted test compound $(20$ $\mu L)$. Non-specific binding was measured by the substitution of a previously prepared analog (75 $\mathrm{mM}, 20 \mu \mathrm{L}$ ) for the analog. A set of vials was also prepared with the absence of any analog as a control. Lastly, ${ }^{3} \mathrm{H}-\mathrm{PDBU}(30 \mathrm{nM}, 20 \mu \mathrm{L})$ was added to the vials, the solutions vortexed, incubated at $37^{\circ} \mathrm{C}$ for $90 \mathrm{~min}$, and then put on ice for $15 \mathrm{~min}$. Filters (Whatman GF/B 21mm) were prepared by soaking in a solution of polyethyleneamine $(6 \mathrm{~mL}, 10 \%$ by volume $)$ and water $(200 \mathrm{~mL})$ for $90 \mathrm{~min}$. Prepared buffer solution $(0.5 \mathrm{~mL}, 20 \mathrm{mM}$ Tris $)$ was added to the vials and then the solutions were individually filtered through the previously prepared filters. The filters were washed slowly with buffer $(4.5 \mathrm{~mL})$, placed into scintillation vials, and filled with Universol scintillation fluid $(5 \mathrm{~mL})$. The filters were immediately counted in a scintillation counter (Beckman LS 6000SC). Counts per minute were averaged among three trials at each concentration. The data as then plotted and an $\mathrm{IC}_{50}$ (the concentration of analogue required to displace half of the specific PDBu binding to PKC) was calculated. The $\mathrm{IC}_{50}$ then allowed determination of the $K_{\mathrm{i}}$ for the analog from the equation: $K_{\mathrm{i}}=\mathrm{IC}_{50} /(1+[\mathrm{PDBu}]) / K_{\mathrm{d}}$ of $\left.\mathrm{PDBu}\right)$. The $K_{\mathrm{d}}$ of [ $\left.{ }^{3} \mathrm{H}\right]-\mathrm{PDBu}$ was determined under identical conditions to be $1.17 \mathrm{nM}$. 
Cell Culture and Transfection. ${ }^{\text {ii }}$ Rat basophilic leukemia $2 \mathrm{H} 3$ (RBL) cells were cultured in Dulbecco's Modified Eagle Medium (DMEM) (Invitrogen Life Technologies, Gibco) containing $20 \%$ fetal calf serum with penicillin (50 units $/ \mathrm{mL})$, streptomycin $(50 \mu \mathrm{g} / \mathrm{mL})$, and glutamine (4 $\mathrm{mM}$, Gibco). Cells were maintained at $37{ }^{\circ} \mathrm{C}$ in an atmosphere of $10 \% \mathrm{CO}_{2}$. Two hours prior to transfection, cells were plated onto sterile glass coverslips. The cDNA encoding GFP-tagged full-length PKC isozyme was electroporated into the cells $12 \mathrm{~h}$ before experiments according to the procedure of Teruel and Meyer. iv $^{2}$

Fluorescence Microscopy. Fluorescence images were obtained using the $488 \mathrm{~nm}$ excitation line of a laser scanning confocal microscope (Pascal, Zeiss) and emission was collected through a 505-550 nm band pass filter. Cells were imaged on the stage of an inverted microscope (Axiovert 100M) using a 40x 1.2 NA Zeiss Plan-apo oil immersion objective. For each experiment, a coverslip to which the cells adhered was used to form the base of a metal cell chamber (Molecular Probes). Cells were washed and maintained in Dulbecco's phosphate buffered saline (PBS, Gibco) supplemented with glucose $(10 \mathrm{mM})$. Analogs were dissolved in DMSO and then diluted to the desired concentration in the extracellular buffer shortly before being added to the cells (final concentration $=200 \mathrm{nM}$ ). The final concentration of DMSO that the cells were exposed to did not exceed $0.1 \%$. Unless otherwise stated, each time series lasted $40 \mathrm{~min}$ and images were acquired every $30 \mathrm{~s}$. Reagents were added to the cell chamber after the fifth image in each time series.

Analysis. Images were exported as 12 or 16 bit files and analyzed using Metamorph data analysis software (Universal Imaging). To monitor the translocation small regions of interest were selected in the cytosol of each cell and fluorescence intensity values graphed against time following background subtraction and normalization.

\footnotetext{
${ }^{\mathrm{i}}$ Wender, P. A.; Mayweg, A. V. W.; VanDeusen, C. L. Org. Lett. 2003, 5, 277-279.

${ }^{11}$ Wender, P. A.; Baryza, J. L.; Brenner, S. E.; Clarke, M. O.; Craske, M. L.; Horan, J. C.; Meyer, T. Curr. Drug Disc. Tech. 2004, 1, 1-11.

iii Mochly-Rosen, D.; Koshland, Jr., D. E. J. Biol. Chem. 1987, 262, 2291-2297.

iv Teruel, MN; Meyer, T. Biophys J. 1997, 4, 1785-1796.
} 